\title{
ELIZABETH BISHOP: POET OR CHARACTER? THE RECEPTION OF BISHOP'S WORK IN THE UNITED STATES AND IN BRAZIL
}

Regina M. Przybycien*

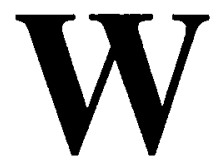

hen Elizabeth Bishop published her first book North \& South and for many years afterwards, her talent was aknowledged and praised mostly by other poets. John Ashbery said of her that she was "the writer's, writer's writer". While some of her friends rapidly became public figures who moved at ease in literary and bohemian circles in New York, she travelled most of the time, shunning the visibility, the public exposure that seemed to accompany a literary career. Thus, for a long time, she was largely ignored by the scholars and the general reading public.

Of an older generation of poets, Marianne Moore was her first mentor and remained her lifelong friend. One can trace Moore's influence in Bishop's early poems, in her formal rigor, in the precision of her images, and in her fastidiousness. Among her contemporaries, Robert Lowell, whom she met in New York right after the publication of her first book, became a close friend, an interlocutor for poetic discussions, and a promoter of her work (it was usually Lowell who learned of poetry awards, sent her the application forms, and

* Universidade Federal do Paraná 
recommended her work for grants). Randall Jarrell, who besides being a poet, was one of the most influential poetry critics of his time, wrote sweeping reviews of her work. John Berryman was a more distant, but equally important, admirer. Her unique style also earned the praises of younger poets like John Ashbery, James Merril, and Frank Bidart.

In Latin America, Bishop established solid relations with several important poets. Living in Mexico for a year, in the forties, she met and made friends with Pablo Neruda, with whom she corresponded sporadically. Neruda went to Ouro Preto in the late sixties, when Bishop already owned a house there. Not finding her in town, he left a message for her, written on the menu of a restaurant, calling her the Nausikaa of Ouro Preto. Neruda remained a private acquaintance, never publishing anything about her. She admired him greatly and declared, in a letter, that she considered him the greatest South American poet. Her only reservations were to his politics: she mistrusted his communism. Octavio Paz, a later but much closer friend, she met in Cambridge, Massachusetts, when she was teaching poetry at Harvard in the early seventies. Paz and Bishop translated each other's poems and Paz published an essay in which he praises Bishop's economy, her "power of reticence"; that is, the almost complete absence of rhetorical devices in her poetry and her capacity to convey a whole world view in a few simple words (Paz, 1975). João Cabral de Melo Neto, writing about her introduction to her translation of Helena Morley's Minha vida de menina, (a childhood diary written in Diamantina in the 1890's and published in the 1940's), admires her for similar reasons. Praising her description of Diamantina, he contrasts her to the majority of Brazilian poets whom, he says, concentrate on the effect that the atmosphere of a place has on them. Bishop, on the other hand, "dá a coisa, comunica-a, agarra a coisa por dentro" (Melo, 1957). João Cabral is probably the Brazilian poet whose poetics (at least in the early stages of his work) more closely resemble Bishop's, in the attempt to convey the bare image, stripped of all kinds of adornments.

When academic criticism of Bishop's poetry started in the United States, the critics followed the trend established by the poets; that is, they made formal analyses of her poems, praising the economy of her language, the freshness and precision of her images, the unexpectness of her rhythms. They usually referred to her deferentially as "Miss" Bishop. "Miss" Bishop was such a good poet that she was compared to the best poets of her generation, namely, the best male poets who wrote "serious" poetry. She herself made a point to be inequivocally placed in the mainstream of American poetry by always refusing to have her poems included in anthologies of women's poetry. For her, poetry belonged to 
a realm beyond the petty concerns of this world, a realm of aesthetics which transcended the politics of class, race and genre.

Her place in the North-American poetic tradition is that of a heiress to the early Modernists. In her poetics, she belongs to the trend established by Wallace Stevens, William Carlos Williams and Mariannne Moore, a trend that values simplicity, compression, and precision. But, undeniably, T.S. Eliot's theories (if not his poetry), left a permanent imprint on the young Bishop, simply because, as David Perkins points out, for more than two decades Eliot's authority in the literary world was unsurpassed by any other critic (Perkins, 1987). Eliot's intellectualism, his insistence that poetry should result from intellectual elaboration and not emotion, became a credo for the young aspiring poets. Bishop's formal rigor was extreme. She sometimes kept a poem for ten, fifteen years, revising it time and again, until she felt it was ready for publication.

At the same time that the creative writers experimented with forms and aimed at objectivity, trying to distance themselves from the artistic products of their imagination, the critics followed the precepts of New Criticism, treating the poem as an autonomous object divorced from the context of its production. They called attention to the language of the poem, encouraging a close reading that would unravel the richness of its rhythms and the complexity of its images.

While Bishop was alive, very little was known of her personal life. In anthologies and literary biographies, information was usually given, in a footnote, to the effect that "Miss" Bishop was living in a mountain town some fifty miles out of Rio de Janeiro, Brazil. She abhorred public exposure, and kept her life as secret as it could possibly be. In Brazil, she could keep her privacy and, at the same time, live her lesbian identity. Only close friends knew that she was sharing a house with a Brazilian woman who was her lover. Few people learned that this love affair ended tragically with her companion's suicide or that Bishop had had a lifelong struggle with alcoholism.

After her death, her papers were sold to the library of Vassar College (where she had studied) and only then, with her letters made available to scholars, her private life was disclosed. One of the first critical works that can be considered a breakthrough in Bishop's criticism is Adrienne Rich's review of her Complete Poems 1927-1979 (Rich, 1983), in which the younger poet considers the theme of outsiderhood present in Bishop's poetry and associates it with her lesbianism. Rich's essay inaugurates a new way of reading Bishop's work, in light of her biography. Instead of focusing on her formal achievements, Rich calls our attention to "her struggles for self-definition and her sense of difference" (Rich, p.15). Thus, Rich inserts the questions of class and genre in 
Bishop's criticism, contextualizing her poetry, a path that has been followed by most critics in the 1980's and 1990's.

A very sensitive critical work is David Kalstone's Becoming a Poet (1989), a literary biography which examines Bishop's relationship with her two great friends, Marianne Moore and Robert Lowell. In this book (published postumously because Kalstone died right before finishing the final draft), we can see the careful balance of biography and criticism, in which one illuminates the other in the construction of the literary "characters" of Moore, Lowell and Bishop. This construction is especially effective because Kalstone is a good writer who, drawing heavily from the three poets'letters, Bishop's drafts, and the testimony of friends, succeeds in creating a compelling narrative which owes nothing to other self-consciously creative narratives. Of course, Kalstone's work is not unique or original in the sense that it reflects a tendency of literary criticism in recent times, which tends to blur the borders between fiction and non-fiction, between the creative and the critical work.

After Kalstone's work, a great number of articles and several books were published which appropriate Bishop as a woman poet or as a lesbian poet or both (see, for instance, Goldensohn, 1992; Lombardi, 1995). This appropriation is part of the politics of minority groups who struggle for a voice and a place in the social arena. Although these readings have many detractors among the more traditional scholars who claim, apocalyptically, that the new academic "left" is killing the great Western literary tradition, (a view shared by the popular media and the Washington politicians), they at least challenge the heretofore unquestioned assumptions that aesthetics belongs to a realm situated beyond and above other human concerns; that is, they foreground the politics of interpretation. That Bishop herself would hate to see her work read in this way is beside the point. The act of reading, like any other activity, is historically and culturally situated, and the creation of meanings results from the relation between the text, the context of its production and the context of its reception. The reader creates meanings in the process of reading, but this creation does not come out of the blue: there is always a text with which he/she enters into a dialogue and, embedded in the physicality of the text, in the signs printed on the page, a whole worldview which belongs to the author function.

The problem with some of the literary criticism in the United States today is the critics's forgetting this relation and embarking in textual voyages of his/her own, constructing fictions which depart completely from the text he/she proposed to interpret. One of the most popular fictions is the literary biography, which has become more and more popular fiction and less and less literary biography. This type of writing exerts a fascination on the reading public. Who 
is not curious about famous people, their joys and miseries, their secrets lives? The writers of biographies create characters that are "real", that inhabit this world and who, at the same time, are marvellous because of their achievements or their fame. The appeal of verossimilitude is irresistible.

It is ironical that two massive biographies of Elizabeth Bishop (Millier, 1993; Brazeau/Fountain, 1994), have already been published when her entire literary production comprises two slim volumes, one of poetry and another of prose (the last published postumously, edited by her publisher, Robert Giroux). Is Bishop's work being overvalued? I don't think so, since much of the critical work published today, including the two biographies, focuses on the character Elizabeth Bishop, not on her texts. The intellectuals seem to have erected her to a kind of cult figure of the gay and lesbian community, presenting her as a woman who lived ahead of her times, who had the courage to live her lesbian identity in exotic settings instead of settling down to a restricted life in her native shores. In short, she is the female Gide who found in Brazil her Afrique noire.

The publication of Bishop's letters, edited by Robert Giroux (1994), only contributes to this general tendency. In his selection of Bishop's letters, Giroux chose those which privilege the personal over the literary life, (at least in those letters written from Brazil). It is true that Bishop was not an erudite, who would spend her time in long literary discussions with friends. Instead, she delighted in describing the curious things and events around her, showing her sharp power of observation. For her minute description of small things, her literary model was Darwin, not Pound or Eliot. However, the few letters which do discuss her poetics were not included in the edition. On the other hand, the many letters written to her doutor Anny Baumann, describing her illnesses, her alcoholism, and other tales of woe are all there for the world to read. Perhaps the intention was for the letters to read as a kind of autobiography which reveals Bishop's personal life "as it really was", instead of having other people's construction of it. But the editing, with its inclusions, exclusions, and chronology creates a narrative which is itself a fiction (not to mention the fact the letters themselves are constructions of fragments of reality). Thus, even the collection of published letters constructs the character Elizabeth Bishop, albeit a different one from the other biographies.

The reception of Bishop's work in Brazil follows a curious but somewhat unfortunate path. While she lived in the country, few Brazilians knew she was a poet, and those who did know, probably did not have much of a sense of the value of her poems. In the early fifties, through her companion Lota de Macedo Soares, she met Manuel Bandeira, who became a friend for some time. She gave him the jellies she cooked, and he thank her with a poem à la cummings in 
PRZYBYCIEN, R. M. Elizabcth Bishop: poct or character?

English. She answered his poem with one of hers, full of witty and ironical allusions to Bandeira as a public figure, (like his participation, as a judge, in the beauty pageant that elected Marta Rocha Miss Brasil). Bandeira later included his poem in a published collection. Bishop never published hers (a fact that confirms her poetic rigor and his lack of it). The friendship with Bandeira drifted away, and she never had a close contact with any other Brazilian poet. She did admire João Cabral a great deal, but while she lived in Brazil, he was on diplomatic service in Europe, so they seldom saw each other.

The media discovered her on three occasions: when The Diary of Helena Morley was published in New York, when she won the Pulitzer prize (imagine the surprise to discover that the Pulitzer prize winner lived in Brazil!), and when she published an article in The New York Times about Rio in its fourth centennial celebration. Because her article did not praise Rio as it should, a reporter from Correio da Manhã called her a racist and suggested that yankees should go home. That created some polemics which soon dissolved into the flood of more recent news. Of her poems, one was a relative success in Rio: "The Burglar of Babylon", the ballad about a thief from the Rio slums who is caught by the police. It merited several translations, none of them very good.

In the seventies, two articles appeared in Brazilian newspapers resulting from interviews that Bishop gave to the reporters (Colonia, 1970; Schiller, 1977). These articles provide some illuminating comments about her poetry, her translations of Brazilian poems and her views of Brazil, although they are newspaper pieces, and therefore, somewhat superficial.

Recent criticism of Bishop's work has consisted mainly in reviews of the translations of her work. In 1990, the publication of a bilingual edition of a selection of her poems merited a trip of the poet and critic Lloyd Schwartz (sponsored by the USIA) to a dozen Brazilian cities to promote the book. He was interviewed by all the major newspapers in the country, which ran big headlines and displayed photos of both Bishop and Schwartz. Unfortunately, the edition was not worth the effort: the translation was bad, full of gross errors of interpretation and rendered in a gongorian style that was the antithesis of Bishop's simple, straighforward language (Bishop, 1990). The best review of this edition was Augusto Massi's, which makes an assessment of Bishop's poetic achievements and points out the failures of the translation (Massi, 1990).

The publication of Bishop's letters (Bishop, 1995), nicely translated by Paulo Henriques Britto, caught the attention of some major Brazilian critics, who reviewed the book (Costa Lima, 1996; Martins, 1996). Almost simultaneously with the publication of her letters, a biography which tells the love story of Lota de Macedo Soares and Elizabeth Bishop was also published (Oliveira, 
1995). This biography, which can be read as a lesbian sentimental novel, has all the necessary ingredients of a best-seller: action, interesting and funny descriptions, swift dialogues, several secondary characters. If the American biographies and the collected letters have already projected Bishop as a character, this book constructs a character called Elizabeth Bishop in the traditional sense of the word, that is, as the novelist's fictional creation. That the creation is based on the historical person and on a thorough research of her life done by the author does not make the book less of a novel. It only gives us the illusion of verossimilitude. Perhaps the problem with Carmen de Oliveira's book is that it remains in a blurred zone between the biographical pact and the fictional creation. This novel and a long and sensational article in a São Paulo newspaper inaugurates the gossipy type of Bishop criticism in Brazil (Felinto, 1995).

It is ironical that the character Elizabeth Bishop suddenly becomes famous in Brazil while the poet remains virtually unknown. While Bishop's only book of prose is now also available in Portuguese (Bishop, 1996), a good anthology of her poems is still missing. Her poems about Brazil, as well as the influence of Brazilian poets on her late work, deserve the attention of the Brazilian critics. Several American critics attribute the shift in Bishop's late poetic production to Lowell's confessional poetry. My view is that it was Carlos Drummond de Andrade, not Lowell, who taught her to balance intensely personal themes with an ironical tone in her memory poems.

It is also ironical that Bishop who, in many ways came to Brazil to hide her lesbian identity, made the headlines of a Brazilian newspaper, with captions like "Map of a Brazilian love" or "I'd like you to meet my lesbian friend, Mary McCarthy would say", or that her story appeared on prime time television in a program about homosexuality. Furthermore, a Rio newspaper has announced that Flávio Barreto, the movic director, wants to make a film about Bishop and her Brazilian lover.

The serious attempt by American criticism to include the politics of gender in literary studies has been somewhat twisted and subverted in Brazil. Most of the Brazilian publications about Bishop seem to indicate, first, that we insist on being colonized, importing the most recent theories together with the most modern electronic gadgets. Second, that the imported theories suffer a kind of carnivalization that transforms them into something else, for Bishop criticism in Brazil up to now does not show a deliberate choice to read her work from the perpective of gender studies. It explores the character Elizabeth Bishop as a product of the media (so much so that most of the articles were published in newspapers and magazines), adopting a celebratory, often uncritical, tone and 
giving the readers bits of anecdotal stories of her passage through Brazil and of her lesbian identity.

\section{RESUMO}

Este trabalho se propõe a analisar a fortuna crítica da obra da poeta Elizabeth Bishop nos Estados Unidos e no Brasil, detendo-se nas transformações que marcaram os processos de leitura de sua obra poética nas últimas décadas, do formalismo textual da Nova Crítica ao historicismo que reinstala o contexto da obra, culminando no "biografismo" que transforma a poeta em personagem.

Palavras-chave: Elizabeth Bishop, poesia americana modema, biografia, crítica literária.

\section{ABSTRACT}

This paper intends to analyze the criticism about the poet Elizabeth Bishop in the United States and in Brazil. It focuses on the changes that occurred in the reading strategies in the last decades: from the formal readings of the New Critics to the New Historicism which reinstates the context of the work's production to, finally, a kind of "biografism" which transforms the poet into a character.

criticism.

Key words: Elizabeth Bishop, modern american poetry, biography, literary

\section{BIBLIOGRAPHY}

BISHOP, Elizabeth. Poemas. Trad. de Horácio Costa. São Paulo: Cia. das Letras, 1990. . Uma arte: as cartas de Elizabeth Bishop. Trad. de Paulo Henriques Britto. São Paulo: Cia. das Letras, 1995. . Esforços do afeto. Prosa. Trad. de Paulo Henriques Britto. São Paulo: Cia. das Letras, 1996. 
COLONIA, Regina. A Poesia como "way of life". Jornal do Brasil, Rio de Janeiro, p. 8, 6 jun. 1970.

FELINTO, Marilene. Feijão preto, amor e diamantes. Folha de S. Paulo, p. 5/4-5/7, 24 nov. 1995.

FOUNTAIN, Gary; BRAZEAU, Peter. Remembering Elizabeth Bishop: an oral biography. Amherst: University of Massachusetts Press, 1994.

GIROUX, Robert (Ed.). One Art: Elizabeth Bishop: Letters. New York: Farrar Straus \& Giroux, 1994.

GOLDENSOHN, Lorrie. Elizabeth Bishop: the biography of a poetry. New York: Columbia University Press, 1992.

KALSTONE, David. Becoming a poet. New York: Farrar Straus \& Giroux, 1989.

LIMA, Luiz Costa. Bishop: a arte da perda. Jornal do Brasil, Rio de Janeiro, p. 7, 3 fev. 1996.

LOMBARDI, Marilyn May. The body and the song: Elizabeth Bishop's poetics. Carbondale and Edwardsville: Southern Illinois University Press, 1995.

MASSI, Augusto. Aprendiz de estrangeiro. Jornal do Brasil, Rio de Janeiro, p. 3-5, 10 mar. 1990.

MARTINS, Wilson. Cartas literárias. Gazeta do Povo, Curitiba, p. 4, 29 abr. 1996.

MELO NETO, João Cabral. Letter to Elizabeth Bishop, June 2, 1957. Special Collections, Vassar College Library.

MILLIER, Bret C. Elizabeth Bishop: life and the memory of it. Berkeley, Los Angeles, Oxford: University of California Press, 1993.

OLIVEIRA, Carmen de. Flores raras e banalissimas. Rocco, 1995. A poeta do desterro. Bravo!, n. 6, p. 66-70, 6 mar. 1998.

PAZ, Octavio. Elizabeth Bishop o el poder de la reticencia. Plural, v. 10, n. 49, p. 6-7, oct. 1975.

PERKINS, David. A history of modern poetry. Cambridge: Harvard University Press, 1987.

RICH, Adrienne. The eye of the outsider: the poetry of Elizabeth Bishop. Boston Review, Apr. 1983. p.15-17.

SCHILLER, Beatriz. Elizabeth Bishop: a poesia que nasceu do sofrimento. Jornal do Brasil, Rio de Janeiro, 8 maio 1997. Revista de Domingo, p. 22-25.

WERNECK, Humberto. Uma casa bem assombrada. $A \& D$, São Paulo, n. 218, p. 26-37, mar. 1998. 